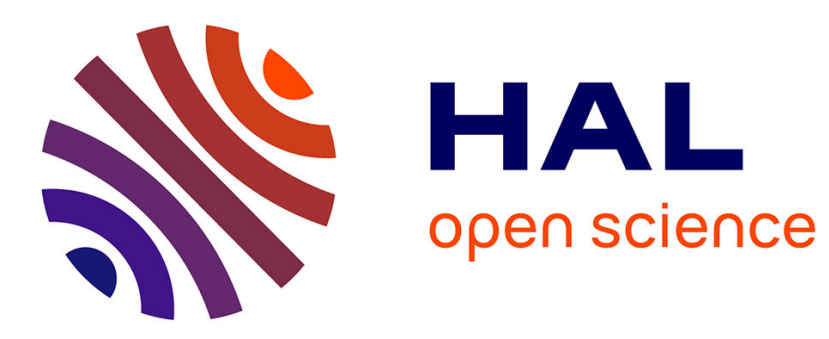

\title{
Making Kraepelin history: a great instauration?
}

Eric J. Engstrom, Matthias M. Weber

\section{To cite this version:}

Eric J. Engstrom, Matthias M. Weber. Making Kraepelin history: a great instauration?. History of Psychiatry, 2007, 18 (3), pp.267-273. 10.1177/0957154X07080819 . hal-00570904

\section{HAL Id: hal-00570904 https://hal.science/hal-00570904}

Submitted on 1 Mar 2011

HAL is a multi-disciplinary open access archive for the deposit and dissemination of scientific research documents, whether they are published or not. The documents may come from teaching and research institutions in France or abroad, or from public or private research centers.
L'archive ouverte pluridisciplinaire HAL, est destinée au dépôt et à la diffusion de documents scientifiques de niveau recherche, publiés ou non, émanant des établissements d'enseignement et de recherche français ou étrangers, des laboratoires publics ou privés. 


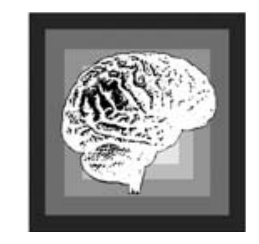

\title{
Introduction to Special Issue
}

\section{Making Kraepelin history: a great instauration?}

\author{
ERIC J. ENGSTROM* \\ Humboldt University, Berlin \\ MATTHIAS M. WEBER \\ Max-Planck-Institute of Psychiatry, Munich
}

\begin{abstract}
This introduction surveys the literature on Kraepelin's legacy and assesses efforts on the part of neo-Kraepelinians to install him as a new, post-Freudian 'father' of clinical psychiatry. It argues that in contemporary discourse Kraepelin has become a touchstone of professional loyalties and that he is put to use in the strategic organization and apportionment of disciplinary resources, power and knowledge.
\end{abstract}

Keywords: Emil Kraepelin; history; neo-Kraepelinian; psychiatric nosology; psychiatry

For more than a century, Emil Kraepelin's work has been the subject of ongoing and contentious debate. By the end of his career, observers had already begun taking stock of his ouvre and moulding his legacy. In the Festschrift published on the occasion of his 70th birthday, contributors assessed his life's work, selectively appropriating or dismissing it, and jockeying for position as heirs to his psychiatric estate ('Festschrift', 1926). After Kraepelin's death in 1926, the retrospective reassessments continued unabated in numerous obituaries and commemorative publications. ${ }^{1} \mathrm{~A}$ decade later in 1938, Robert Gaupp believed that his work was 'indestructible' and that it comprised nothing less than the 'precondition of all research' in psychiatry and the foundation of Nazi racial hygiene laws (Gaupp, 1939: 47-8). Upon the centennial of Kraepelin's birth in 1956, another German psychiatrist insisted that 'practically the entire civilized world was indebted

\footnotetext{
* Address for correspondence: Institut für Geschichte der Medizin, Charité - Universitätsmedizin Berlin, Ziegelstrasse 5-9, 10117 Berlin, Germany. Email: eric.engstrom@charite.de
} 
to Kraepelin for its psychiatric nosology'. ${ }^{2}$ On the same occasion, Kraepelin's student Walter Gruhle remarked that his views on neurosis and psychosis 'provided almost no support' for current research and that his psychology had 'nothing worthwhile' to contribute (Gruhle, 1956: 243-4). In 1959 Eugen Kahn dismissed Kraepelin's terminology as 'antiquated' (Kahn, 1959: 33) and by the 1960s he had, in the words of Henri Ellenberger (1970: 285), become a popular 'whipping boy' for many psychiatrists.

More recently of course, neo-Kraepelinian psychiatrists have been eager to enshrine Kraepelin as their historical lodestar - as a new, post-Freudian 'father' of clinical psychiatry, of DSM-III, and of applied quantitative methods. They have granted his work near paradigmatic status, turning to him as they grapple with questions such as whether disease entities exist, what endophenotypes modulate clinical pictures, or how to measure mental processes in reliable and valid ways (Andreasen, 2001; Blashfield, 1984; Klerman, 1989; Shorter, 1997). They have repeatedly evoked his legacy in support of efforts to strengthen the biomedical model of mental disorder, maintain psychiatry's status within the mental health professions, and reinforce its position as a research-based specialty within medicine (Mayes and Horowitz, 2005; McCarthy and Gerring, 1994). In other words, what some have described as a 'revolutionary' (Compton and Guze, 1995; Klerman, 1989:31) paradigm shift in psychiatry over the past quarter century has gone hand-in-hand with recourse to Kraepelin's name and work. But inasmuch as the 'revolutionary' changes in contemporary psychiatry reflect a return to Kraepelinian precepts, those changes might more aptly be described as a 'restoration' or better, perhaps, as a neo-Baconian 'instauration' (Bacon, 1960 [1620]). Like Francis Bacon's attempt to re-establish the foundations of science on empirical and experimental foundations after the long and purportedly benighted Middle Ages, so too do neo-Kraepelinians see themselves returning to first scientific principles after the allegedly misguided interlude of psychodynamic psychiatry. As Nancy Andreasen (1997: 108) has remarked: in moving forward, psychiatric research has found itself 'returning to the past and coming back full circle to the work of Kraepelin'.

No doubt spurred on by this looking back in admiration, scholars have contributed to a growing body of literature on Kraepelin's life and work (Burgmair, Engstrom and Weber, 2000-2006; Decker, 2004; Hoff, 1994; Jablensky, 1995). Many authors have sought validation (or less frequently falsification) of contemporary research by comparing either specific disease categories or methodological techniques such as longitudinal analysis with Kraepelin's results. ${ }^{3}$ Others have been eager to locate in his work the primal origins of other fields such as psychopharmacology (Müller, Fletcher and Steinberg, 2006) or comparative and transcultural psychiatry (Boroffka, 1990; Jilek, 1995; Steinberg, 2002: 23). ${ }^{4}$

Needless to say, these views have not gone unchallenged. Indeed, from the outset, these instaurative accounts have been questioned from numerous 
quarters, especially in conjunction with critiques of DSM. Medical anthropologists have articulated constructivist critiques of the new psychiatric taxonomy (Gaines, 1992; Lock, 1987). Sociologists have drawn attention to the complex socio-economic factors contributing to its rapid spread (Mayes and Horowitz, 2005). Philosophers and historians have warned of reductive implications of Kraepelin's nosologies and the 'exaggerated sway' in the direction of operational criteria, inductivism, and empiricism that is eroding 'important phenomenological skills' ${ }^{5}$ Clinical psychologists have criticized the diagnostic ethos of the new paradigm and have begun tracing the outlines of a 'post-Kraepelinian psychopathology' (Bentall, 2006: 223; Mirowsky and Ross, 1989). Recently, molecular geneticists have also begun pronouncing the beginning of the end of the Kraepelinian dichtomy, citing evidence that genes confer susceptibility 'across the Kraepelinian divide' and insisting that the time has come to relegate neo-Kraepelinian psychiatry to the historical dustbin (Craddock and Owen, 2005).

Such conflicting accounts remind us of how Kraepelin's legacy has acquired a history of its own. They point to the different interpretive and narrative stages which have been built up around Kraepelin's historical personage and on which he has been made to strut and fret his part in a play not necessarily of his own design. They suggest a whole choreography of retrospective mobilizations aimed at either legitimizing or delegitimizing contemporary psychiatric work. On these different stages, Kraepelin can be seen to play a variety of different roles. Often he stands simply as a chiffre for biological psychiatry, for a dichotomous classification of the psychoses, or for empirical and quantitative methodologies. He can also serve as a kind of a surrogate voice in plots about the validation or falsification of contemporary diagnoses. At times his role appears similar to that of other iconic figures such as Philippe Pinel and Sigmund Freud, simply serving as a backdrop or prop for an altogether different narrative drama. As such, Kraepelin has become a kind of touchstone of professional loyalties, put to dramatic use in the strategic organization and apportionment of disciplinary resources, power and knowledge.

One of the most striking characteristics of this contemporary discourse is its anachronistic flavour. A recent standard work on bipolar disorders suggests direct lines of Kraepelinian continuity extending not just forward to contemporary molecular and epidemiological research, but also back through Early Modern times to antiquity. In other accounts one could be forgiven for believing that Kraepelin was himself a neo-Kraepelinian - a kind of psychiatric time traveller to St Louis or Iowa City in the 1960s and 1970s. The surprising thing about such recourse to Kraepelin is that his work is more likely to be interpreted in relation to Hippocratic medicine or DSM-IV than to the specific historical contexts and clinical practices from which they emerged in the decades preceding World War I. 
Such anachronistic stagings of Kraepelin are problematic because they provide scant means of resisting the reification of his nosology - something that he himself would, and did, decisively reject. Furthermore, they expose the poverty of our understanding about the processes that contribute to the formulation of psychiatric nosologies. One of the achievements of recent scholarship is a growing recognition that Kraepelin's classifications derived from a complex interplay of factors that included cultural and philosophical assumptions, and clinical research practices, as well as administrative and institutional contexts, all of which ultimately left their traces in the categories that he delineated and believed to be (rightly or wrongly) somatically grounded. ${ }^{6}$

Given the contested nature of Kraepelin's name in contemporary discourse and the fact that the reception of his work has been the object of so little scholarly attention, the aim of this Special Issue is to begin analysing his legacies and their deployment in different historical contexts. Our original plan was to publish a collection of papers on the reception of Kraepelin's work post-1926. We had hoped to solicit contributions on his influence in Europe, the Americas, the Far East, etc. But this ambitious vision quickly ran headlong into the sober realities of contemporary historical scholarship - realities that at once demonstrated how glaringly utopian our original plan was, but that also confirmed the dire need for more research on the transmission and dissemination of Kraepelin's teachings. ${ }^{7}$

Our greatest regret and the most glaring omission in this collection is the absence of a contribution on Kraepelin's reception in Germany in the midtwentieth century. ${ }^{8}$ We plan to redress this deficiency soon, in a separate article. In the meantime, perhaps the Classic Text, although it cannot fill the void, goes some way towards fostering further discussion on Kraepelin's legacy in National Socialist Germany.

We hope that this Special issue of History of Psychiatry will enliven scholarly debate on Kraepelin's twentieth-century legacy and restore a dimension of complexity to it - a dimension which has sometimes got lost in acrimonious debate. Perhaps it will encourage researchers to revisit their preconceptions of Kraepelin and give them pause for thought when, for whatever reason, they invoke his name in contemporary discourse. Studying the history of his different legacies can help us to hone and temper our assessments of his influence. And by preserving and enhancing the complexity of our historical understanding, it can deliver a useful platform from which to assess the contingencies of contemporary practice and consequently better manage our critiques, expectations and hopes for psychiatry's future.

\section{Acknowledgements}

The guest editors wish to express their gratitude to Wolfgang Burgmair and the Max-PlanckInstitute for Psychiatry in Munich for their support in preparing this Special Issue. We also appreciate the encouragement and support of German Berrios. 


\section{Notes}

1. Among many others, see: Aschaffenburg, 1929; Gaupp, 1926; Groß, 1929; Gruhle, 1929; Mayer-Gross, 1929; Rüdin, 1929; Spielmeyer, 1927.

2. Franz-Günther von Stockert as cited in Kahn, 1956: 192.

3. To cite but a few prominent examples, see: Benazzi, 2004; Boyle, 1990; Häfner, 2004; Jablensky, 1999; Kendler, 1986, 1988; Rabinowitz, 2005; Rössler-Riecher and Rössler, 1998; Segal, 1989; Trede et al., 2005.

4. For a rebuttal of these views, see Oda, Banzato and Dalgalarrondo, 2005. For one of the more expansive visions of his influence, see: Ast, 1999, and the views expressed on the webpage of the International Kraepelin Society (IKS) at www.kraepelin.org.

5. See the editor's comments in Weber and Engstrom, 1997: 383; also, Hoff, 1992; Roelcke, 1997.

6. See: Berrios and Hauser, 1988; Burgmair, et al., 2000-2006; Engstrom, 2003: 121-46; Hoff, 1992; McGorry, 1998; Roelcke, 1999. McGorry speaks in this context of the 'clinician's illusion.'

7. There has been some work on the reception of Kraepelin's work outside Germany. For the case of Great Britain, see Beer and Ion, 2002. On Kraepelin's influence in the USA, see Meyer, 2003; Noll, 2004.

8. But two recent German dissertations have begun surveying the reception of Kraepelin's views in Germany; see: Feldmann, 2005; Palm, 2006.

\section{References}

Andreasen, N. C. (1997) The evolving concept of schizophrenia: from Kraepelin to the present and future. Schizophrenia Research, 28, 105-9.

Andreasen, N. C. (2001) Brave New Brain: Conquering Mental Illness in the Era of the Genome (Oxford: Oxford University Press).

Aschaffenburg, G. (1929) Der Einfluß Kraepelins auf die Kriminalpsychologie und Kriminalpolitik. Archiv für Psychiatrie und Nervenkrankheiten, 87, 88-95.

Ast, M. (1999) Kraepelin's vision for modern scientific psychiatry. Paper presented to the 11 th World Congress of Psychiatry, Hamburg, Germany, 8 August 1999.

Bacon, F. (1960 [1620]) The New Organon and Related Readings (Indianapolis: Bobbs-Merrill).

Beer, D. and Ion, R. M. (2002) The British reaction to dementia praecox, 1893-1913. Parts 1 and 2. History of Psychiatry, 13, 285-304, 419-32.

Benazzi, F. (2004) Is depressive mixed state a transition between depression and hypomania. European Archives of Psychiatry and Clinical Neuroscience, 254, 69-75.

Bentall, R. (2006) Madness explained: why we must reject the Kraepelinian paradigm and replace it with a 'complaint-oriented' approach to understanding mental illness. Medical Hypothesis, 66, 220-33.

Berrios, G. E. and Hauser, R. (1988) The early development of Kraepelin's ideas on classification - a conceptual history. Psychological Medicine, 18, 813-21.

Blashfield, R. K. (1984) The Classification of Psychopathology: Neo-Kraepelinian and Quantitative Approaches (New York: Plenum).

Boroffka, A. (1990) Emil Kraepelin (1856-1926). Transcultural Psychiatry, 27, 228-37.

Burgmair, W., Engstrom, E. J. and Weber, M. M. (2000-2006) Emil Kraepelin Edition, Vols I-VI (Munich: belleville).

Boyle, M. (1990) Is schizophrenia what it was? A re-analysis of Kraepelin's and Bleuler's population. Fournal of the History of the Behavioral Sciences, 26, 323-32.

Compton, W. M. and Guze S. B. (1995) The neo-Kraepelinian revolution in psychiatric diagnosis. European Archives of Psychiatry and Clinical Neuroscience, 245 (4-5), 196-201. 
Craddock, N. and Owen, M. J. (2005) The beginning of the end of the Kraepelinian dichotomy. British fournal of Psychiatry, 186, 364-6.

Decker, H. S. (2004) The psychiatric world of Emil Kraepelin: a many-faceted story of modern medicine. Fournal of the History of Neurosciences, 13, 248-76.

Ellenberger, H. F. (1970) The Discovery of the Unconscious: The History and Evolution of Dynamic Psychiatry (New York: Basic Books).

Engstrom, E. J. (2003) Clinical Psychiatry in Imperial Germany: A History of Psychiatric Practice (Ithaca: Cornell University Press).

Feldmann, S. (2005) Die Verbreitung der Kraepelinischen Krankheitslehre im deutschen Sprachraum zwischen 1893 und 1912 am Beispiel der Dementia praecox (Medical dissertatation; Giessen: University of Giessen).

'Festschrift für Emil Kraepelin' (1926) Zeitschrift für die gesamte Neurologie und Psychiatrie, 101 (Special Issue).

Gaines, A. G. (1992) From DSM-I to III-R: voices of self, mastery and the other: a cultural constructivist reading of U.S. psychiatric classification. Social History of Medicine, 35 (1), 3-24.

Gaupp, R. (1926) Emil Kraepelin. Süddeutsche Monatshefte, 24, 219-22.

Gaupp, R. (1939) Die Lehren Kraepelins in ihrer Bedeutung für die heutige Psychiatrie. Zeitschrift für die gesamte Neurologie und Psychiatrie, 165, 47-75.

Groß, A. (1929) Kraepelins Bedeutung für die Anstaltspsychiatrie. Archiv für Psychiatrie und Nervenkrankheiten, 87, 50-67.

Gruhle, H.W. (1929) Kraepelins Bedeutung für die Psychologie. Archiv für Psychiatrie und Nervenkrankheiten, 87, 43-9.

Gruhle, H. W. (1956) Emil Kraepelins 100. Geburtstag. Der Nervenarzt, 27, 241-4.

Häfner, H. (2004) Schizophrenia: still Kraepelin's dementia praecox? Epidemiologia e Psichiatria Sociale, 13 (2), 99-112.

Hoff, P. (1992) Emil Kraepelin and philosophy: the implicit philosophical assumptions of Kraepelinian psychiatry. In M. Spitzer et al. (eds), Phenomenology, Language and Schizophrenia (New York: Springer), 115-25.

Hoff, P. (1994) Emil Kraepelin und die Psychiatrie als klinische Wissenschaft: Ein Beitrag zum Selbstverständnis psychiatrischer Forschung (Berlin: Springer).

Jablensky, A. (ed.) (1995) Emil Kraepelin and 20th century psychiatry. Special Issue. European Archives of Psychiatry and Clinical Neuroscience, 245 (4-5).

Jablensky, A. (1999) The conflict of the nosologists: views on schizophrenia and manicdepressive illness in the early part of the 20th century. Schizophrenia Research, 39, 95-100.

Jilek, W. G. (1995) Emil Kraepelin and comparative sociocultural psychiatry. European Archives of Psychiatry and Clinical Neuroscience, 245 (4-5), 231-8.

Kahn, E. (1956) Emil Kraepelin: ein Gedenkblatt zum 100. Geburtstag. Monatsschrift für Psychiatrie und Neurologie, 131, 190-2.

Kahn, E. (1959) Emil Kraepelin memorial lecture. In B. Pasamanick (ed.), Epidemiology of Mental Disorder (Washington DC: American Association for the Advancement of Science, Publication No. 60), 1-38.

Kendler, K. S. (1986) Kraepelin and the differential diagnosis of dementia praecox and manic-depressive insanity. Comprehensive Psychiatry, 27, 549-58.

Kendler, K. S. (1988) Kraepelin and the diagnostic concept of paranoia. Comprehensive Psychiatry, 29, 4-11.

Klerman, G. L. (1989) Psychiatric diagnostic categories: issues of validity and measurement. Fournal of Health and Social Behavior, 30, 26-40.

Lange, J. (1926) Emil Kraepelin. Die Naturwissenschaften, 14, 1255-6. 
Lock, M. (1987) DSM-III as a culture-bound construct. Culture, Medicine and Psychiatry, $11,35-42$.

Mayer-Gross, W. (1929) Die Entwicklung der klinischen Anschauungen Kraepelins. Archiv für Psychiatrie und Nervenkrankheiten, 87, 30-42.

Mayes, R. and Horowitz, A. V. (2005) DSM-III and the revolution in the classification of mental illness. Fournal of the History of the Behavioral Sciences, 41 (3), 249-67.

McCarthy, L. P. and Gerring, J. P. (1994) Revising psychiatry's charter document DSM-IV. Written Communication, 11 (2), 147-92.

McGorry, P. D. (1998) 'A stitch in time'... the scope for preventive strategies in early psychosis. European Archives of Psychiatry and Clinical Neuroscience, 248, 22-31.

Meyer, A. (2003) Remarks on Hecker's address. History of Psychiatry, 14 (4), 493-508.

Mirowsky, J. and Ross, C. E. (1989) Psychiatric diagnosis as reified measurement. Fournal of Health and Social Behavior, 30, 11-25.

Müller, U., Fletcher, P. C. and Steinberg, H. (2006) The origin of pharmacopsychology: Emil Kraepelin's experiments in Leipzig, Dorpat and Heidelberg (1882-1892). Psychopharmacology, 184, 131-8.

Noll, R. (2004) The American reaction to dementia praecox. History of Psychiatry, 15 (1), $127-8$.

Oda, A. M. G. R., Banzato, C. E. M. and Dalgalarrondo, P. (2005) Some origins of crosscultural psychiatry. History of Psychiatry, 16 (2), 155-69.

Palm, U. (2006) Auseinandersetzung mit Kraepelins Werk in den fahren 1900 bis 1960 (Medical dissertation; Munich: University of Munich).

Rabinowitz, J. (2005) Association between functioning in adolescence prior to first admission for schizophrenia and affective disorders and patterns of hospitalizations thereafter. Schizophrenia Research, 73, 185-91.

Roelcke, V. (1997) Biologizing social facts: an early 20th century debate on Kraepelin's concepts of culture, neurasthenia, and degeneration. Culture, Medicine and Psychiatry, $21,383-403$.

Roelcke, V. (1999) Laborwissenschaft und Psychiatrie: Prämissen und Implikationen bei Emil Kraepelins Neuformulierung der psychiatrischen Krankheitslehre. In C. Gradmann and T. Schlich (eds), Strategien der Kausalität. Konzepte der Krankheitsverursachung im 19. und 20. Fahrhundert (Pfaffenweiler: Centaurus), 93-116.

Rössler-Riecher, A. and Rössler, W. (1998) The course of schizophrenic psychoses: what do we really know? A selective review from an epidemiological perspective. European Archives of Psychiatry and Clinical Neuroscience, 248, 189-202.

Rüdin, E. (1929) Kraepelins sozialpsychiatrische Grundgedanken. Archiv für Psychiatrie und Nervenkrankheiten, 87, 76-86.

Segal, J. H. (1989) Erotomania revisited: from Kraepelin to DSM-III-R. American fournal of Psychiatry, 146, 1261-6.

Shorter, E. (1997) A History of Psychiatry: From the Era of the Asylum to the Age of Prozac (New York: John Wiley \& Sons).

Spielmeyer, W. (1927) Kraepelin und die naturwissenschaftlich-medizinische Forschung in der Psychiatrie. Zeitschrift für die gesamte Psychiatrie und Neurologie, 108, 10-20.

Steinberg, H. (2002) Der Briefwechsel zwischen Wilhelm Wundt und Emil Kraepelin: Zeugnis einer jahrzehntelangen Freundschaft (Bern: Hans Huber).

Trede, K., Salvatore, P., Baethge, C., Gerhard, A., Maggini, C. and Baldessarini, R. J. (2005) Manic depressive illness: evolution in Kraepelin's textbook, 1883-1926. Harvard Review of Psychiatry, 13, 155-78.

Weber, M. M. and Engstrom, E. J. (1997) Kraepelin's diagnostic cards: the confluence of empirical research and preconceived categories. History of Psychiatry, 8, 375-85. 